\title{
Defect- and H-Free Stoichiometric Silicon Carbide by Thermal CVD from the Single Source Precursor Trisilacyclohexane
}

\author{
Alain E. Kaloyeros ${ }^{1}$, Jonathan Goff ${ }^{2}$ (D) and Barry Arkles ${ }^{3, *(D)}$ \\ 1 BFD Innovation, Slingerlands, NY 12159, USA; akaloyeros@gmail.com \\ 2 Gelest Inc., Morrisville, PA 19067, USA; jgoff@gelest.com \\ 3 Department of Chemistry, Temple University, Phiadelphia, PA 19122, USA \\ * Correspondence: barry.arkles@temple.edu
}

Citation: Kaloyeros, A.E.; Goff, J.; Arkles, B. Defect- and H-Free Stoichiometric Silicon Carbide by Thermal CVD from the Single Source Precursor Trisilacyclohexane. Electron. Mater. 2022, 3, 27-40. https://doi.org/10.3390/ electronicmat 3010003

Academic Editor: Sylvia Matzen

Received: 23 November 2021

Accepted: 7 January 2022

Published: 10 January 2022

Publisher's Note: MDPI stays neutral with regard to jurisdictional claims in published maps and institutional affiliations.

Copyright: (C) 2022 by the authors. Licensee MDPI, Basel, Switzerland. This article is an open access article distributed under the terms and conditions of the Creative Commons Attribution (CC BY) license (https:// creativecommons.org/licenses/by/ $4.0 /)$.

\begin{abstract}
Stoichiometric silicon carbide $(\mathrm{SiC})$ thin films were grown using thermal chemical vapor deposition (TCVD) from the single source precursor 1,3,5-trisilacyclohexane (TSCH) on c-Si (100) substrates within an optimized substrate temperature window ranging from 650 to $850{ }^{\circ} \mathrm{C}$. X-ray photoelectron spectroscopy (XPS) and Fourier transform infrared spectroscopy (FTIR) analyses revealed that the as-deposited films consisted of a Si-C matrix with a Si:C ratio of $\sim 1: 1$. FTIR and photoluminescence (PL) spectrometry studies showed that films deposited $\geq 750{ }^{\circ} \mathrm{C}$ were defect- and $\mathrm{H}$-free within the detection limit of the techniques used, while ellipsometry measurements yielded an as-grown $\mathrm{SiC}$ average refractive index of $\sim 2.7$, consistent with the reference value for the $3 \mathrm{C}-\mathrm{SiC}$ phase. The exceptional quality of the films appears sufficient to overcome limitations associated with structural defects ranging from failure in high voltage, high temperature electronics to 2-D film growth. TSCH, a liquid at room temperature with good structural stability during transport and handling as well as high vapor pressure $\left(\sim 10\right.$ torr at $\left.25^{\circ} \mathrm{C}\right)$, provides a viable single source precursor for the growth of stoichiometric $\mathrm{SiC}$ without the need for post-deposition thermal treatment.
\end{abstract}

Keywords: silicon carbide; $\mathrm{SiC}$; chemical vapor deposition; CVD; thin film; organosilicon

\section{Introduction}

Silicon carbide $(\mathrm{SiC})$ thin films are currently the subject of an intense revival in research and development activities for potential use in diverse emerging technological applications [1,2]. This renewed interest is driven by silicon carbide's many attractive properties, including excellent mechanical hardness and chemical inertness, which make it an ideal protective coating in applications that require operating at elevated temperatures, in highly corrosive environments, and/or under severe mechanical stress [3-5]. SiC films also serve as the host matrix in three exciting new areas of technical innovation. In power electronics, $\mathrm{SiC}$ enables the fabrication of high-voltage, high-current devices that can be operated at elevated temperatures [6-8]; $\mathrm{SiC}$ is also increasingly used in micro-electro-mechanical-systems (MEMS) due to its higher thermal conductivity, higher voltage power, and higher breakdown voltage compared to Si [3]; In nanophotonics, quantum and nonlinear photonics technologies exploit a wide array of $\mathrm{SiC}$ properties, including high refractive index, strong second- and third-order optical nonlinearity, and a broad ultra-violet-to-mid-infrared transparency window [9-12]. For these reasons, $\mathrm{SiC}$ also acts as a base platform for a number of optically addressable spin qubits [13].

$\mathrm{SiC}$ thin films also constitute key building blocks in optical, optoelectronic, and electronic systems, including photoluminescent devices, due to their wide band gap and elevated electrical breakdown voltage [14-17]. They also act as excellent passivation and encapsulation layers and/or diffusion and permeation barriers in integrated circuitry (IC) and solar cells-including crystalline Si-based heterojunction solar cells-as well as lightemitting devices (LEDs), organic LEDs (OLEDs), and myriad other planar optical systems 
and optical waveguides [17-20]. Additionally, among recently emerging applications, it is worth nothing that $\mathrm{SiC}$ and transition metal oxide thin films are being studied as prospective contenders for incorporation in electronic synapse devices for neuromorphic computing applications [21,22].

Despite their potential for the purposes discussed above, significant challenges must still be overcome in order to extend the use of $\mathrm{SiC}$ thin films to emerging industrial applications. The absence of practical, economic paths to high quality silicon carbide substrates, particularly thin film substrates, have inhibited commercialization [23]. Defects in thin films and deposition conditions for the formation of the thin films are primary obstacles. For example, traditional $\mathrm{SiC}$ chemical vapor deposition (CVD) processes rely on the high temperature reaction of hydride- or halo-silane precursors such as $\mathrm{SiH}_{4}, \mathrm{Si}_{2} \mathrm{H}_{6}$, and $\mathrm{SiCl}_{4}$ with carbon-containing precursors such as $\mathrm{CHCl}_{3}, \mathrm{C}_{3} \mathrm{H}_{4}, \mathrm{C}_{2} \mathrm{H}_{2}$, and $\mathrm{CCl}_{4}$. The inherent challenges associated with such chemistries are well documented, and include their pyrophoric and corrosive nature, numerous environmental, health, and safety issues, the incorporation of high levels of $\mathrm{H}$ into the resulting $\mathrm{SiC}$ films, and the need for postdeposition annealing to achieve the desired $\mathrm{SiC}$ film specifications. However, it is highly desirable for good quality $\mathrm{SiC}$ to possess minimal levels of two distinct types of $\mathrm{H}$ defect: (i) substitutional bonding of $\mathrm{H}$ to $\mathrm{Si}$, which prevents a 1:1 Si:C stoichiometry, and (ii) $\mathrm{H}$ dopant (including interstitial H) [24,25].

Efforts that have been made to address these challenges include using plasma-assisted atomic layer deposition (PA-ALD) of 1,3,5-trisilacyclohexane (TSCH) at temperatures below $600{ }^{\circ} \mathrm{C}$ [26], applying ultra-violet light treatment to selectively remove specific precursor ligands and attachments from a $\mathrm{Si}, \mathrm{C}$, and $\mathrm{H}$-containing precursor to realize molecular layer deposition [27], and employing remote plasma processes to form plasma effluents that generate a flowable layer of a 1,3,5-trisilapentane-type precursor on a substrate [26,27]. However, all of these methods failed to deposit stoichiometric $\mathrm{SiC}$, instead yielding films consisting of Si-C-H network arrangements with different ratios of $\mathrm{Si}$ to $\mathrm{C}$, varying $\mathrm{H}$ contents, and significant defect densities.

It is therefore desirable to provide a thermal (non-plasma based) CVD technique that overcomes the drawbacks of the deposition methods listed above by forming high-quality, stoichiometric $\mathrm{SiC}$ thin films with negligible as-deposited defects and $\mathrm{H}$ content while simultaneously eliminating the issues associated with current $\mathrm{Si}$ and $\mathrm{C}$ source precursors. To this end, this report focuses on the development and optimization of a TCVD process from the single source precursor 1,3,5-trisilacyclohexane ( $\left.\mathrm{TSCH}, \mathrm{C}_{3} \mathrm{H}_{12} \mathrm{Si}_{3}\right)$, a silahydrocarbon in which every $\mathrm{C}$ atom is bonded to two $\mathrm{Si}$ atoms, with each $\mathrm{Si}$ atom being additionally bonded to two $\mathrm{H}$ atoms. The bond structure and energies associated with $\mathrm{H}$ atoms in this silahydrocarbon precursor suggest the potential for two distinct decomposition processes: (i) an elimination reaction in which a Si-C double bond structure "silene" is formed, and (ii) loss of $\mathrm{H}$ from $\mathrm{Si}$, forming a "silylene". Both of these processes are shown schematically below (Scheme 1): 
<smiles></smiles><smiles>C1CC1</smiles><smiles>C1=[SiH]CC=[SiH][SiH2]1</smiles><smiles>C[13CH3]</smiles><smiles>[2H][C@H]1C[SiH2]C[SiH]1[2H]</smiles>

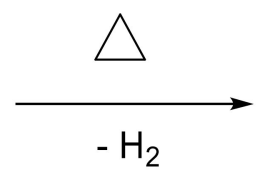<smiles></smiles>

Scheme 1. Potential decomposition processes of the single source precursor 1,3,5-trisilacyclohexane (TSCH, $\mathrm{C}_{3} \mathrm{H}_{12} \mathrm{Si}_{3}$ ). Top: An elimination reaction in which a Si-C double bond structure "silene" is formed. Bottom: Loss of $\mathrm{H}$ from Si, forming a "silylene".

The end result is a stoichiometric, as-deposited $\mathrm{SiC}$ thin films with no $\mathrm{H}$ inclusion. Importantly, this ability to form $\mathrm{H}$-free $\mathrm{SiC}$ films will eliminate the need for high-temperature post-deposition annealing to remove $\mathrm{H}$.

The compositional and optical properties of the as-deposited SiC films were analyzed using Fourier transform infrared spectroscopy (FTIR), X-ray photoelectron spectroscopy (XPS), atomic force microscopy (AFM), scanning electron microscopy (SEM), spectroscopic ellipsometry, and photoluminescence (PL) in the visible optical spectrum. The results are summarized and discussed below.

\section{Materials and Methods}

\subsection{Precursor Synthesis}

The reader is cautioned that pyrophoric starting materials and byproducts are present in this synthetic procedure. All equipment was acid washed and dried at $125^{\circ} \mathrm{C}$ before assembly. A 4-neck $5 \mathrm{~L}$ flask equipped with a mechanical stirrer, pot thermometer, heating mantle, vapor phase argon inlet with shut-off valve, and Vigreux column mounted with a short-path distillation head was connected to a $1 \mathrm{~L}$ 3-neck receiving flask in a cooling bath. The receiving flask was mounted with a dry-ice condenser and a 3-way valve leading alternately to a vacuum pump and an argon bubbler. $800 \mathrm{~g}$ of hexaethoxytrisilacyclohexane was then loaded into the flask. Vacuum was then applied to the system (1 torr), which was subsequently vented to atmospheric pressure with argon. After ensuring that there were no vacuum leaks, the procedure was repeated. A slow argon purge was flowed through the reaction flask and exited through the argon bubbler. The reaction flask was then warmed to $40^{\circ} \mathrm{C}$. Next, $1805 \mathrm{~g}$ of diisobutylaluminum hydride was added to the stirred flask over $2.5 \mathrm{~h}$ while maintaining the pot temperature below $55^{\circ} \mathrm{C}$.

After the addition was complete, the mixture was stirred for an additional $45 \mathrm{~min}$ at $50{ }^{\circ} \mathrm{C}$. The argon sparge was then halted, and a short-path distillation was initiated after charging dry-ice to the receiving flask condenser and cooling the receiving flask to $\sim{ }^{\circ} \mathrm{C}$ (the reader should be warned that the resulting product freezes at $\sim-10^{\circ} \mathrm{C}$, and that overcooling can lead to orifice blockage). A vacuum of 2 torr was applied while maintaining the pot temperature at $55^{\circ} \mathrm{C}$ for $8 \mathrm{~h}$ and collecting crude TSCH in the receiving flask. The system was then allowed to cool and vented again with argon. The receiving flask containing the $\mathrm{TSCH}$ crude product was removed from the reaction train and the TSCH crude product 
was redistilled through a 0.3-m Raschig ring packed column with a distillation head. As a result, $230 \mathrm{~g}$ of TSCH was collected at a boiling point of $71-74{ }^{\circ} \mathrm{C}$ at 75 torr. The final product was $>98 \%$ pure, as measured by gas chromatography (selected properties of TSCH are presented in Table 1). TSCH is flammable but not pyrophoric. It generates hydrogen in contact with bases and platinum. Separately, in order to lessen the hazard inherent in the reaction byproducts, a $1 \mathrm{~L}$ 3-neck flask was reconnected to the reaction train as previously described. $2500 \mathrm{~g}$ of sec-butanol was added at a rate ensuring that the pot temperature remained below $35{ }^{\circ} \mathrm{C}$ in order to neutralize any excess diisobutylaluminum hydride reactant as well as the diisobutylaluminum ethoxide byproduct. The resulting isobutane was vented in diluted form through the argon bubbler. It should be noted that the precursor synthetic method can also be employed to synthesize other silahydrocarbons, such as 1,3,5,7-tetrasilanonane and 1,3,5-trisilapentane.

Table 1. Pertinent properties of Trisilacyclohexane (TSCH).

\begin{tabular}{|c|c|}
\hline Property & Value \\
\hline \multicolumn{2}{|l|}{ Chemical Structure } \\
\hline Molecular Formula & $\mathrm{C}_{3} \mathrm{H}_{12} \mathrm{Si}_{3}$ \\
\hline Molecular Weight (g) & 132.38 \\
\hline Melting Point $\left({ }^{\circ} \mathrm{C}\right)$ & -10 \\
\hline Boiling Point $\left({ }^{\circ} \mathrm{C}\right)$ & 136@760 torr \\
\hline Density $\left(\mathrm{g} / \mathrm{cm}^{3}\right), 20^{\circ} \mathrm{C}$ & 0.9001 \\
\hline Vapor Pressure (torr), $35^{\circ} \mathrm{C}$ & $\sim 10$ torr \\
\hline Heat of Vaporization (kJ/mole) & 43.2 \\
\hline Refractive Index, $\mathrm{n}^{\mathrm{D}}, 20^{\circ} \mathrm{C}$ & 1.5059 \\
\hline FTIR & $2130 \mathrm{~cm}^{-1}, \mathrm{Si}-\mathrm{H}$, very strong \\
\hline${ }^{1} \mathrm{HNMR}\left(\mathrm{CDCl}_{3}\right)$ & ${ }^{1} \mathrm{HNMR}\left(\mathrm{CDCl}_{3}\right): 0.01(\mathrm{~m}, 6 \mathrm{H}), 4.09(\mathrm{~m}, 6 \mathrm{H})$ \\
\hline Flash Point, $\left({ }^{\circ} \mathrm{C}\right)$ & 11 \\
\hline
\end{tabular}

\subsection{Thermal CVD Processing Conditions}

A custom-made hot-wall CVD system equipped with a quartz tube reactor and a turbopump manifold was employed for TCVD process development and optimization. All depositions were performed on c-Si(100) substrates and double-polished intrinsic silicon for infrared studies. The substrates were pre-cleaned with acetone and isopropanol (IPA), in that order, and were then rinsed with deionized (DI) water prior to loading into the reactor. The substrates were then loaded in the reactor and subjected to a pre-deposition heat treatment in an argon (Ar) atmosphere. The TSCH precursor was loaded into a specialized bubbler which was connected to the CVD system and heated to $50^{\circ} \mathrm{C}$. All delivery lines were also heated to $90^{\circ} \mathrm{C}$ to prevent precursor condensation prior to entering the reaction chamber. Ar was employed as the diluent gas.

Process development and optimization for TCVD SiC from the single source precursor TSCH was carried out using a design-of-experiments (DOE) approach, wherein a systematic set of deposition experiments (listed in Table 2) were conducted to identify optimum processing conditions for the growth of stoichiometric $\mathrm{SiC}$ thin films with negligible as-deposited defect and $\mathrm{H}$ densities. The source precursor 1,1,3,3-tetramethyl1,3-disilacyclobutane (TMDSB; $\mathrm{C}_{6} \mathrm{H}_{16} \mathrm{Si}_{2}$ ) was additionally employed as a baseline in order to compare the optical properties of the resulting $\mathrm{SiC}$ films with their counterparts derived from TSCH. TMDSB was selected because it is also a single source precursor and has been extensively tested in recent studies of the growth of $\mathrm{SiC}$ films and nanophotonic structures. 
Table 2. Design of experiments (DOE) processing parameters for TCVD SiC.

\begin{tabular}{|c|c|c|c|c|c|c|}
\hline Run & $\begin{array}{l}\text { Precursor Source } \\
\text { Temperature }\left({ }^{\circ} \mathrm{C}\right)\end{array}$ & Precursor & $\begin{array}{l}\text { Precursor Flow } \\
\text { Rate (sccm) }\end{array}$ & $\begin{array}{c}\text { Substrate } \\
\text { Temperature } \\
\left({ }^{\circ} \mathrm{C}\right)\end{array}$ & Pressure (torr) & $\begin{array}{l}\text { Ar Dilution } \\
\text { Gas Flow Rate } \\
\text { (sccm) }\end{array}$ \\
\hline 1 & $50{ }^{\circ} \mathrm{C}$ & $\begin{array}{c}\text { TMDSB } \\
\text { (for comparison) }\end{array}$ & 10 & 800 & 1 & 400 \\
\hline 2 & $50{ }^{\circ} \mathrm{C}$ & TSCH & 1 & 400 & 1 & 200 \\
\hline 3 & $50{ }^{\circ} \mathrm{C}$ & $\mathrm{TSCH}$ & 1 & 450 & 1 & 200 \\
\hline 4 & $50{ }^{\circ} \mathrm{C}$ & $\mathrm{TSCH}$ & 1 & 500 & 1 & 200 \\
\hline 5 & $50{ }^{\circ} \mathrm{C}$ & $\mathrm{TSCH}$ & 1 & 550 & 1 & 200 \\
\hline 6 & $50{ }^{\circ} \mathrm{C}$ & $\mathrm{TSCH}$ & 1 & 600 & 0.2 & 200 \\
\hline 7 & $50{ }^{\circ} \mathrm{C}$ & TSCH & 1 & 650 & 0.2 & 200 \\
\hline 8 & $50{ }^{\circ} \mathrm{C}$ & $\begin{array}{c}\text { TMDSB } \\
\text { (for comparison) }\end{array}$ & 10 & 800 & 1.5 & 400 \\
\hline 9 & $50{ }^{\circ} \mathrm{C}$ & TSCH & 1 & 700 & 0.2 & 200 \\
\hline 10 & $50{ }^{\circ} \mathrm{C}$ & $\mathrm{TSCH}$ & 1 & 750 & 0.2 & 200 \\
\hline 11 & $50{ }^{\circ} \mathrm{C}$ & $\mathrm{TSCH}$ & 1 & 800 & 0.2 & 200 \\
\hline 12 & $50{ }^{\circ} \mathrm{C}$ & $\mathrm{TSCH}$ & 1 & 850 & 0.2 & 200 \\
\hline
\end{tabular}

\section{Analytical Techniques}

For spectroscopic ellipsometry (SE), film thickness was determined using a Woollam RC2 dual rotating compensator ellipsometer capable of measurements in the wavelength range from 250 to $1000 \mathrm{~nm}$ at an incident angle of $75^{\circ}$. A structure consisting of three layersnamely, ambient (air), one layer ( $\mathrm{SiC})$, and substrate (c-Si) — was utilized to simulate the optical functions (refractive index $\mathrm{n}$, extinction coefficient $\mathrm{k}$ ) of the thin films using the data acquired from the SE measurements.

For photoluminescence (PL) studies, steady-state PL measurements were recorded using a continuous Xe arc lamp for excitation in a fluorescence spectrometer (FLSP920 Edinburgh Instruments, Edinburgh Instruments, Livingston, UK). Spectra were corrected for the detector's response variation with wavelength. The various bonding configurations in the samples were investigated by Fourier Transform Infrared Spectroscopy (FTIR) analyses in the infrared range of $400-4000 \mathrm{~cm}^{-1}$ with a resolution of $8 \mathrm{~cm}^{-1}$. Spectra were collected using a Nicolet iS50 FTIR spectrometer (Thermo Fisher, Waltham, MA, USA). After baseline subtraction, all spectra were corrected for variations in film thickness. Additionally, the surface roughness was determined via atomic force microscopy (AFM) using a Bruker Dimension Icon system (Bruker, Billerica, MA, USA) in contact mode with a tip radius of $2 \mathrm{~nm}$. X-ray photoelectron spectroscopy (XPS) was carried out with a PHI Quantera Hybrid system (Physical Electronics, Chanhassen, MI, USA), with Al K-alpha source directed with a $23^{\circ}$ acceptance angle and $45^{\circ}$ take-off angle. Film composition analysis was performed with an Ar ion gun at $3 \mathrm{keV}, 3 \mathrm{~mm} \times 3 \mathrm{~mm}$ raster, and $\sim 3 \mathrm{~nm} / \mathrm{min}$ sputter rate. Depth profile and binding energy spectra analysis was completed using PHI Multi Pack software (Physical Electronics, Chanhassen, MI, USA).

TSCH vapor pressure was determined using a pressure-cell differential scanning calorimetry (DSC) system consisting of a TA Instruments Pressure DSC $25 \mathrm{P}$ instrument (TA Instruments, New Castle, DE, USA) with Tzero Hermetic Pinhole (75 $\mu \mathrm{m})$ Lids. The sample size was $2-5 \mathrm{mg}$ and the ramp rate was set at $15^{\circ} \mathrm{C} / \mathrm{min}$.

\section{Results and Discussion}

\subsection{Precursor Selection}

In addition to its advantageous chemical structure and bonding configuration-including a 1:1 Si:C ratio and high vapor pressure, as shown in Figure 1-1,3,5-trisilacyclohexane (TSCH, $\mathrm{C}_{3} \mathrm{H}_{12} \mathrm{Si}_{3}$ ) was chosen because it can be synthesized in high volume and exceptional purity from readily accessible base reagents (as described in Section 2.1 above), a characteristic that is particularly beneficial for efforts to incorporate TSCH into large scale industrial manufacturing. 


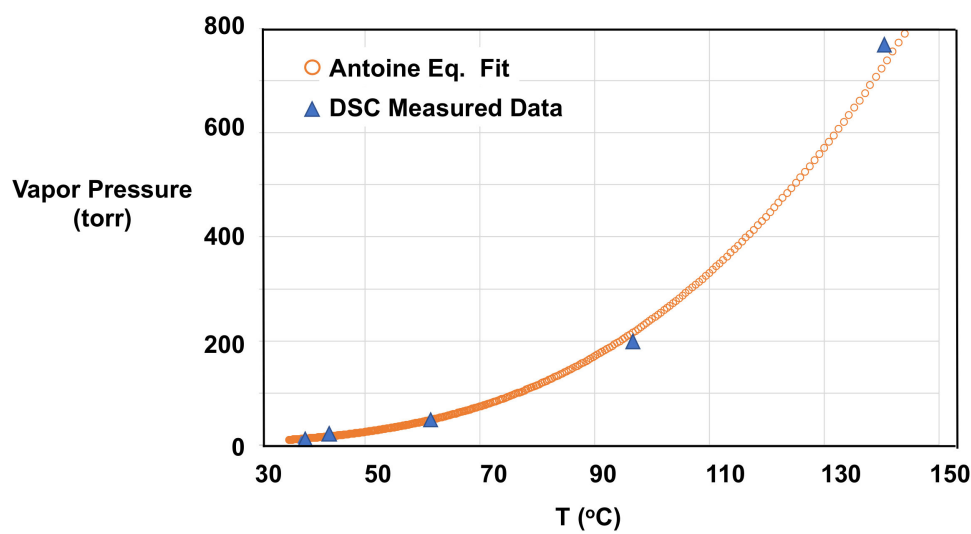

Figure 1. TSCH vapor pressure data acquired from DSC measurements. The experimental data were fitted to an Antoine Equation over the range of 0.14 to 760 torr.

\subsection{XPS Analysis}

$\mathrm{Si}, \mathrm{C}$, and $\mathrm{O}$ concentrations versus penetration depth were examined in the asdeposited SiC films using XPS depth profile analyses. A representative depth profile for as-deposited $\mathrm{SiC}$ films grown at substrate temperatures of $850{ }^{\circ} \mathrm{C}$ is shown in Figure 2. The analyses demonstrated a Si-to-C ratio of 1:1, indicating that the as-deposited $\mathrm{SiC}$ films are indeed stoichiometric. O was below the detection limits of XPS in the as-deposited films. The high-resolution XPS spectrum for Si2p binding energy is displayed in Figure $3 a$ for $\mathrm{SiC}$ films deposited at $850^{\circ} \mathrm{C}$ : the Si2p peak location at $100.3 \mathrm{eV}$ [28] corresponds to a $\mathrm{Si}-\mathrm{C}$ bonding configuration, further confirming the existence of the $\mathrm{SiC}$ phase. Additionally, the absence of any XPS binding energy peaks at $99 \mathrm{eV}$ and $~ 101.5 \mathrm{eV}$ excludes the existence of Si-Si and Si-C-O bonds [28], respectively, further supporting the findings from the XPS depth profile analysis regarding the absence of $\mathrm{C}$ and $\mathrm{O}$ contamination. These findings are further confirmed by the high-resolution XPS spectrum for the O1s binding energy as displayed in Figure $3 \mathrm{~b}$, which shows that $\mathrm{O}$ concentrations in the as-deposited $\mathrm{SiC}$ films were below the detection limit of XPS.

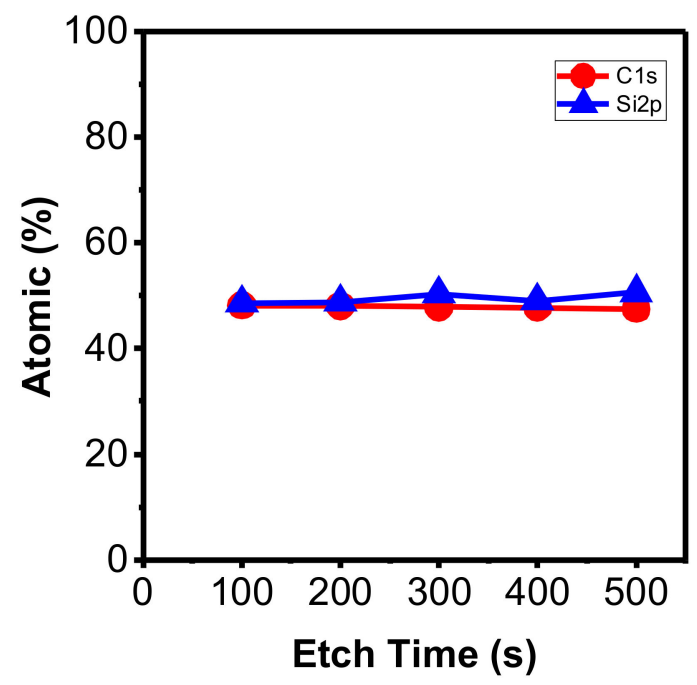

Figure 2. Representative XPS profile of $\mathrm{Si}$ and $\mathrm{C}$ concentrations versus penetration depth in SiC films deposited at $850{ }^{\circ} \mathrm{C}$. 


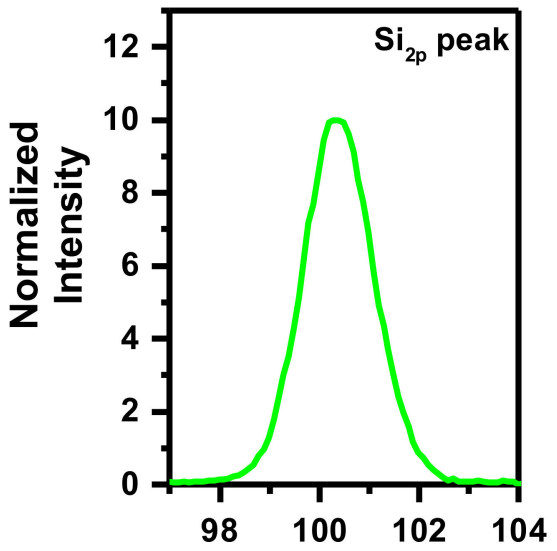

Binding Energy

$(\mathrm{eV})$

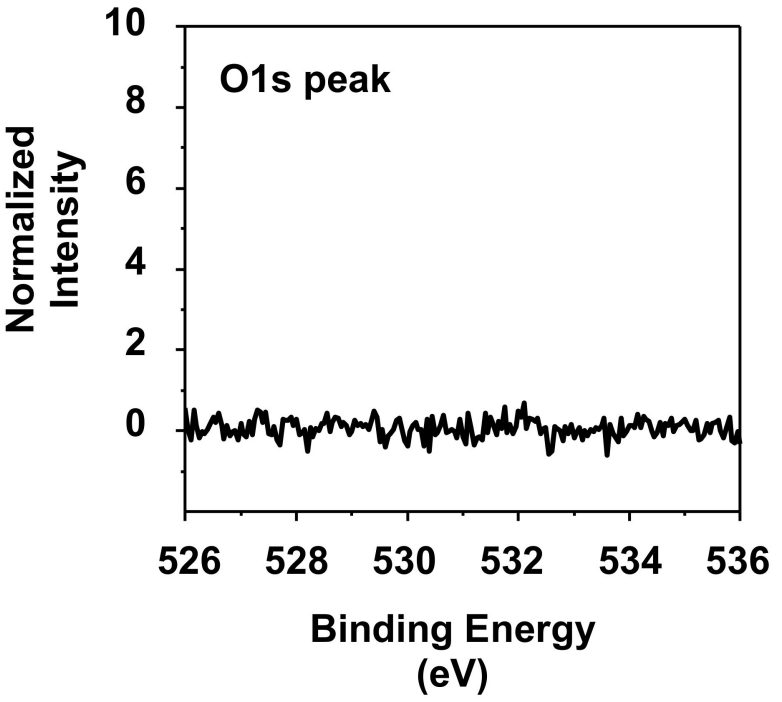

(b)

(a)

Figure 3. Representative high-resolution XPS spectra of: (a) Si2p binding energy for SiC films deposited at $850{ }^{\circ} \mathrm{C}$, corresponding to stoichiometric $\mathrm{Si}: \mathrm{C}$; and (b) O1s binding energy for SiC films deposited at $850^{\circ} \mathrm{C}$, indicating the absence of any $\mathrm{O}$ contamination.

\subsection{FTIR Analysis}

Figure 4 shows the representative normalized absorbance coefficient for the TSCHderived $\mathrm{SiC}$ thin film deposited at $850^{\circ} \mathrm{C}$. The absorption band in the range of $500-1200 \mathrm{~cm}^{-1}$ reveals a single component attributed to the Si-C transverse optical (TO) stretching mode at $\sim 791 \mathrm{~cm}^{-1}$. FTIR studies of the TSCH-grown SiC films were supplemented with measurements of the post-annealed SiC films generated from TMDSB at $1100{ }^{\circ} \mathrm{C}$. The as-deposited TSCH-derived SiC films exhibit a higher degree of crystallinity than the post-annealed SiC films generated from TMDSB. More specifically, the SiC films have a FWHM of $\sim 63 \mathrm{~cm}^{-1}$ comparable to values for high-quality $\mathrm{SiC}$ films grown by other single source precursors [14].

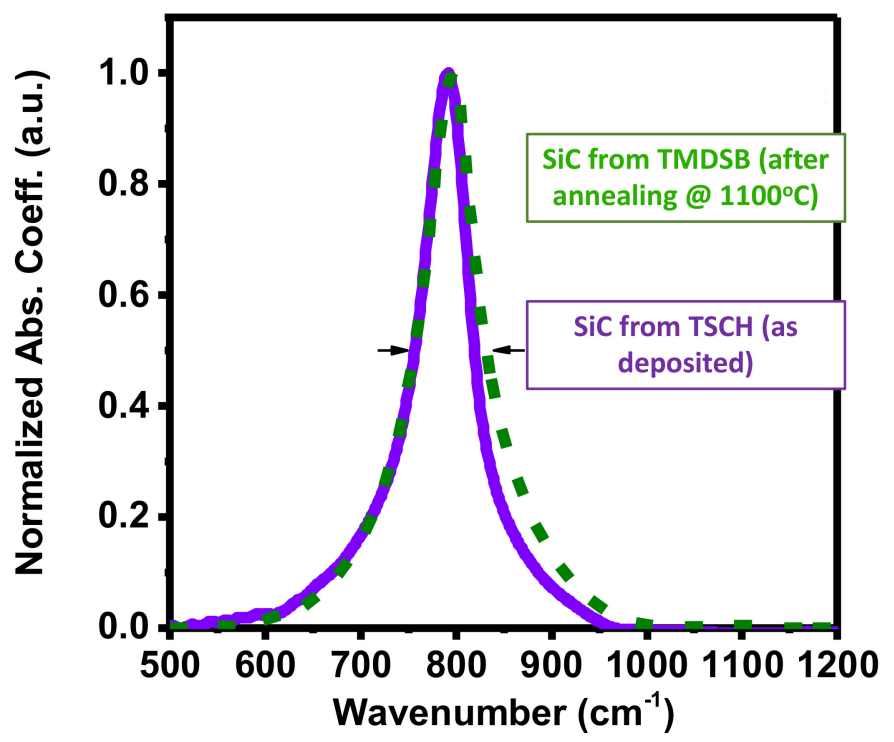

Figure 4. FTIR-normalized absorbance coefficient for as-deposited SiC films using TSCH as the Si precursor compared to post-annealed SiC films grown using TMDSB. 
Figure 5 plots the full width at half maximum (FWHM) and peak positions of the main stretching $\mathrm{Si}-\mathrm{C}$ absorption band as a function of deposition temperature. The profiles indicate decreasing FWHM values with increasing substrate temperature. This decrease is accompanied by a shift in peak position to shorter wavelengths ("blue shift"). Both trends imply an increased level of crystallinity in the as-deposited SiC films with rising substrate temperature-an expected result that can be attributed to the availability of greater thermal energy with higher substrate temperature, enabling the nucleation, coalescence, and growth of larger and more ordered $\mathrm{SiC}$ grains. For comparison, Figure 5 also includes the FWHM for $\mathrm{SiC}$ films grown using TMDSB as a source precursor at a substrate temperature of $800^{\circ} \mathrm{C}$. The $\mathrm{SiC}$ films grown from TMDSB exhibit smaller grain size (and therefore larger grain boundary density) than all their counterparts deposited using TSCH, regardless of substrate temperature.

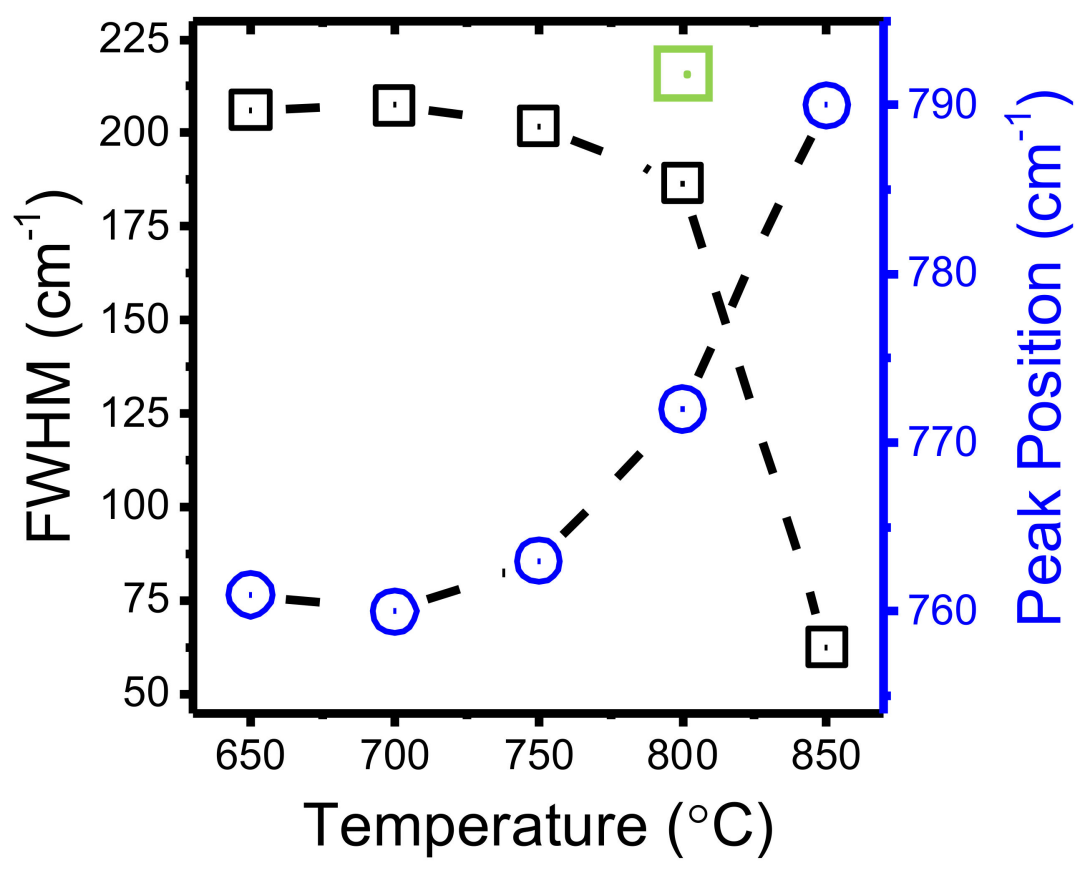

Figure 5. FTIR FWHM and peak position of the main stretching transverse optical (TO) Si-C absorption band as a function of deposition temperature for as-deposited TSCH-derived SiC films. The FWHM for SiC films grown using TMDSB as the source precursor at a substrate temperature of $800{ }^{\circ} \mathrm{C}$ is included for comparison (data point in green).

To better understand hydrogen inclusion, Figure 6a depicts the FTIR spectra for asdeposited $\mathrm{SiC}$ samples grown from $\mathrm{TSCH}$ at $650{ }^{\circ} \mathrm{C}, 700{ }^{\circ} \mathrm{C}$, and $800{ }^{\circ} \mathrm{C}$ in the expanded wavelength range of 500 to $3000 \mathrm{~cm}^{-1}$. The FTIR spectra show: (i) a single, highly intense absorption peak around $800 \mathrm{~cm}^{-1}$ corresponding to the Si-C stretching mode in crystalline $\mathrm{SiC}$; (ii) an extremely weak absorption around $2090 \mathrm{~cm}^{-1}$ corresponding to the Si-H stretching mode for the sample grown at $650{ }^{\circ} \mathrm{C}$. The $\mathrm{Si}-\mathrm{H}$ absorption band is reduced below background signal for the samples deposited $\geq 800{ }^{\circ} \mathrm{C}$, indicating that $\mathrm{H}$ is below the detection limits of FTIR in these samples, as shown in Figure $6 \mathrm{~b}$. The ratio of the Si-H to the $\mathrm{Si}-\mathrm{C}$ bond absorption densities for the as-deposited $\mathrm{SiC}$ samples grown from $\mathrm{TSCH}$ at $650{ }^{\circ} \mathrm{C}$ was $\sim 0.04$; the ratio was reduced to less than zero for the samples grown at $800{ }^{\circ} \mathrm{C}$, indicating the absence of $\mathrm{H}$ within the detection limits of FTIR. 


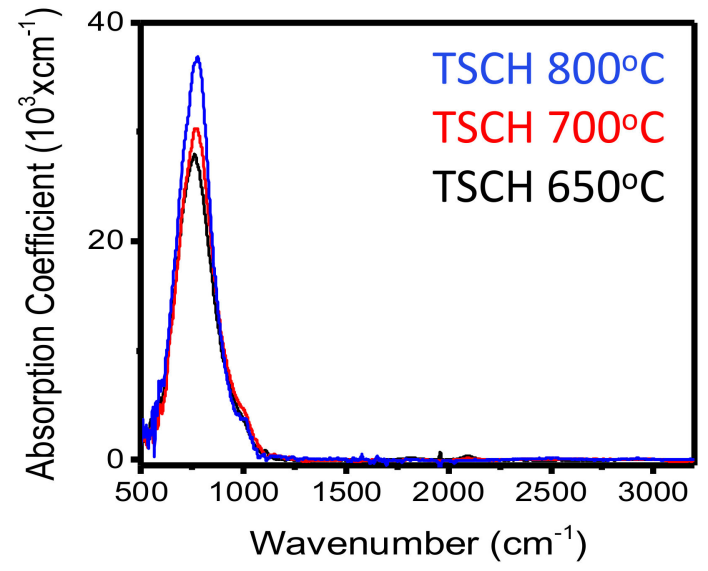

(a)

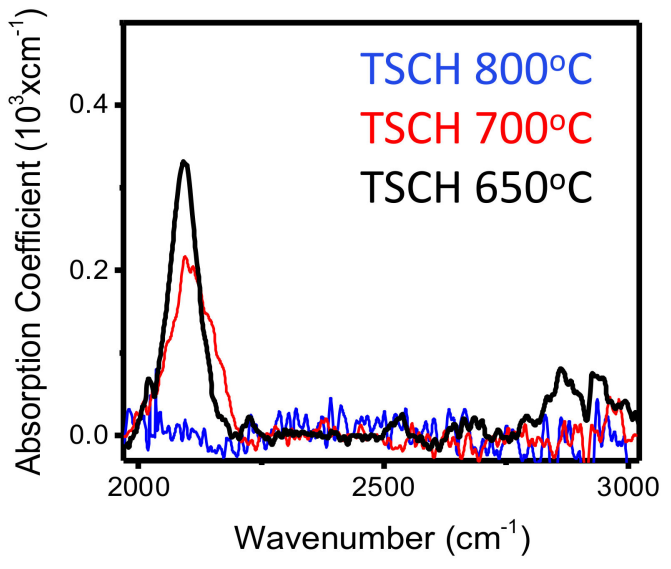

(b)

Figure 6. (a) FTIR-normalized absorbance coefficient for as-deposited SiC films grown from TSCH at three different deposition temperatures $\left(650{ }^{\circ} \mathrm{C}, 700{ }^{\circ} \mathrm{C}\right.$, and $\left.800{ }^{\circ} \mathrm{C}\right)$; $(\mathrm{b})$ section around the stretching transverse optical Si-H absorption located at $2090 \mathrm{~cm}^{-1}$, enlarged to better capture relative Si-H peak size.

\subsection{Ellipsometry Analysis}

Ellipsometry was employed to measure the thickness of as-deposited SiC films grown from TSCH as a function of substrate temperature to determine growth rate versus substrate temperature. Figure 7 shows the growth rate as a function of deposition temperature at 0.2 torr working pressure. As can clearly be seen, $650{ }^{\circ} \mathrm{C}$ was the lowest temperature to yield SiC deposition within the process window investigated, and the growth rate dropped by an order of magnitude with every $50^{\circ}$ drop below $750{ }^{\circ} \mathrm{C}$. The highest growth rate, observed at $850{ }^{\circ} \mathrm{C}$, was $\sim 2.2 \mathrm{~nm} / \mathrm{s}$. This result is anticipated and can be ascribed to the availability of greater thermal energy with higher substrate temperature, thus allowing an increased precursor reaction rate and, therefore, a higher growth rate. It should be noted that the processing parameters within this deposition regime were designed to enable precise thickness control for near-zero thickness $\mathrm{SiC}$ films, as supported by the growth rate data.

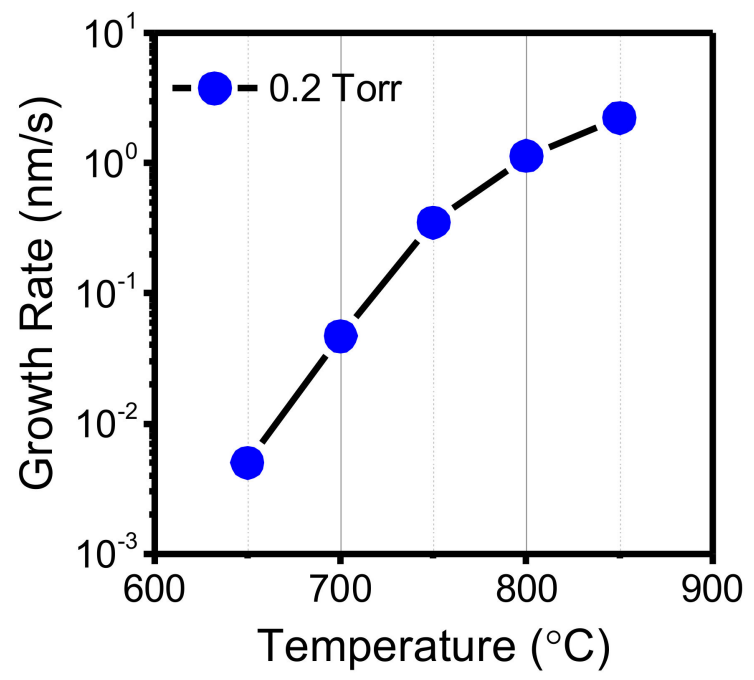

Figure 7. Growth rate as a function of deposition temperature for $\mathrm{SiC}$ films produced via $\mathrm{TSCH}$ at 0.2 torr working pressure.

Ellipsometry was also employed to measure the refractive index (n) and absorption coefficient $(\alpha)$ values for as-deposited SiC films from TSCH at $500 \mathrm{~nm}$ wavelength as a function of substrate temperature. As can be seen in Figure 8 , the $\mathrm{SiC}$ refractive index $\mathrm{n}$ 
varied between 2.9 and 2.7 for all deposition temperatures, which is consistent with the reference value for 3C-SiC (2.7). This finding supports the XPS and FTIR results in terms of the existence of a stoichiometric $\mathrm{SiC}$ phase. Furthermore, a comparison of the normalized absorption coefficient, $\alpha$, for as-deposited $\mathrm{SiC}$ grown from TSCH at $650{ }^{\circ} \mathrm{C}$ versus the TMDSB-derived $\mathrm{SiC}$ sample deposited at $800^{\circ} \mathrm{C}$ is shown in Figure 9. The TSCH-derived $\mathrm{SiC}$ film shows a drastic decrease in sub- $E_{04}$ optical gap absorption $\left(E_{04}\right.$ : energy where $\alpha$ is $10^{4} \mathrm{~cm}^{-1}$ ), in stark contrast to the TMDSB-derived SiC sample, which exhibits high absorption. This behavior clearly demonstrates a significantly lower defect density for $\mathrm{SiC}$ grown at $650{ }^{\circ} \mathrm{C}$ from $\mathrm{TSCH}$ compared to the $\mathrm{SiC}$ sample grown from TMDSB.

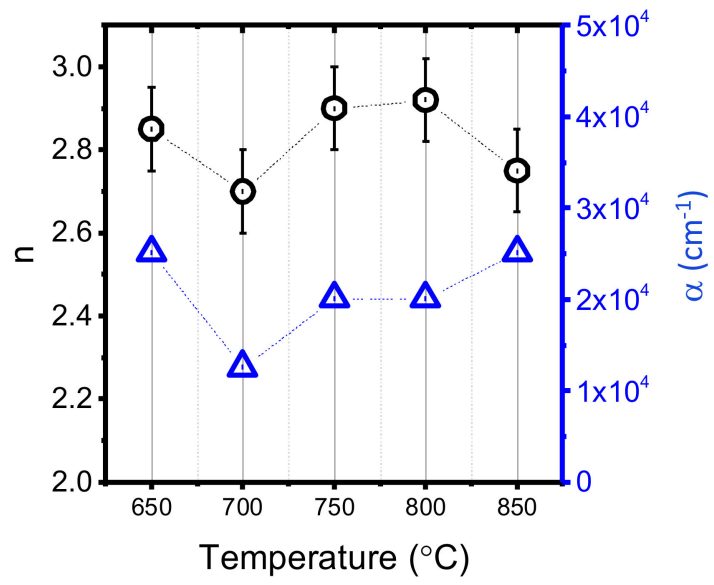

Figure 8. Refractive index (n) and absorption coefficient $(\alpha)$ values for as-deposited TSCH-derived $\mathrm{SiC}$ films versus substrate temperature at a wavelength of $500 \mathrm{~nm}$, as determined by ellipsometry.

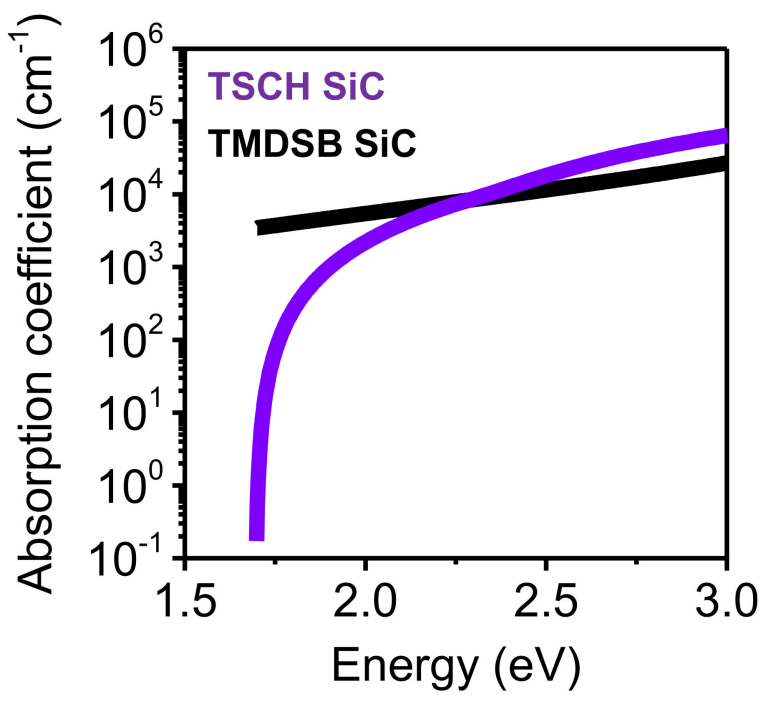

Figure 9. Normalized absorption coefficients for $\mathrm{SiC}$ grown at $650^{\circ} \mathrm{C}$ from $\mathrm{TSCH}$ versus $\mathrm{SiC}$ deposited from TMDSB at $800{ }^{\circ} \mathrm{C}$, as determined by ellipsometry.

\subsection{Photoluminescence Analysis}

Figure 10 compares the PL behavior of as-deposited $\mathrm{SiC}$ films grown at $800^{\circ} \mathrm{C}$ utilizing TSCH and TMDSB precursors. As can be seen in the figure, the TSCH SiC exhibited almost no visible defect-induced PL in the wavelength range from $350 \mathrm{~nm}$ to $600 \mathrm{~nm}$. In contrast, the as-deposited TMDSB SiC sample produced defect-related visible PL, which may be partially attributed to structural and compositional disorder [29,30]. In this context, the FTIR studies highlight that the degree of bond angle disorder (FWHM) is higher for the $800{ }^{\circ} \mathrm{C}$-deposited TMDSB SiC samples. Furthermore, this finding supports the ellipsometry results in terms of the absence of any such defects in the TSCH SiC films, in contrast to 
the TMDSB SiC samples, as evidenced by the substantially higher sub- $E_{04}$ optical gap absorption observed in the TMDSB samples.

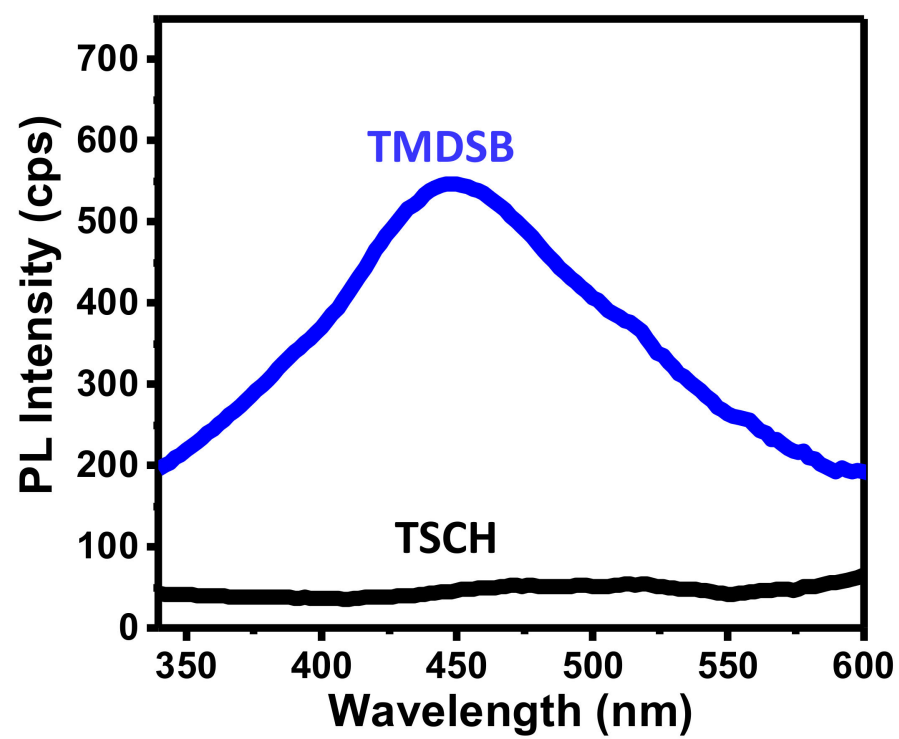

Figure 10. Photoluminescence (PL) measurements for as-deposited SiC films generated using TSCH versus SiC films deposited using TMDSB.

\subsection{Atomic Force Microscopy}

Figure 11 presents an atomic force microscopy (AFM) micrograph for as-deposited $\mathrm{SiC}$ films grown at $650{ }^{\circ} \mathrm{C}$ from TSCH. The mean surface roughness (rms) was determined to be $\sim 0.3 \AA$, comparable to that of a polished Si wafer [14].

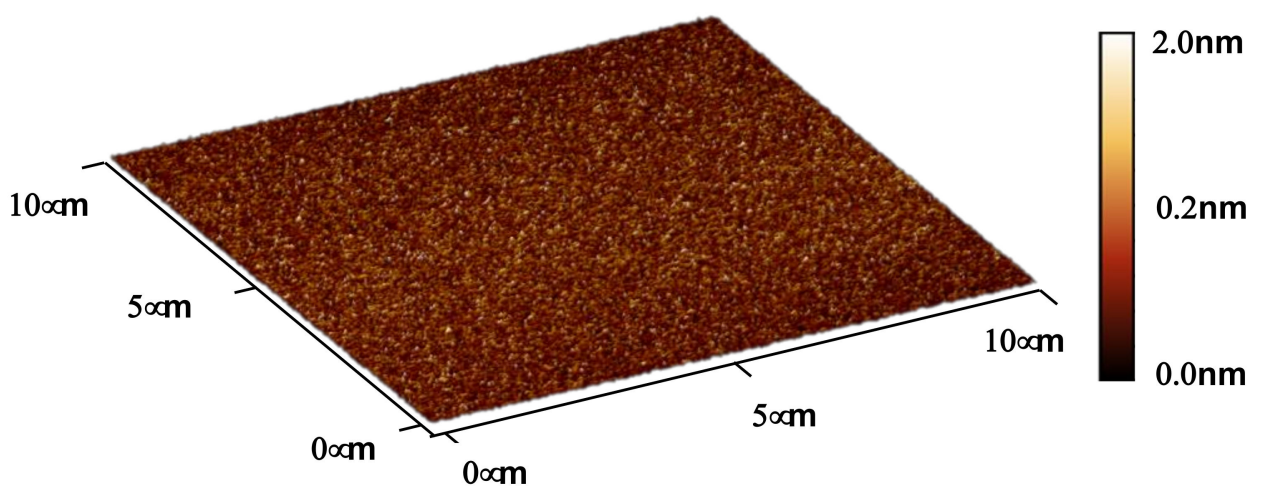

Figure 11. Atomic force microscopy (AFM) micrograph of as-deposited SiC films grown from TSCH at a $650{ }^{\circ} \mathrm{C}$ substrate temperature.

\subsection{Scanning Electron Microscopy}

Figure 12 exhibits scanning electron microscopy (SEM) micrographs for as-deposited SiC films grown from TSCH at: (a) $650{ }^{\circ} \mathrm{C}$, (b) $700{ }^{\circ} \mathrm{C}$, and (c) $800^{\circ} \mathrm{C}$. The mean surface roughness (rms) was determined to increase from $0.3 \mathrm{~nm}$ to $0.5 \mathrm{~nm}$ to $1.5 \mathrm{~nm}$ for the samples grown at $650{ }^{\circ} \mathrm{C}, 700^{\circ} \mathrm{C}$, and $800{ }^{\circ} \mathrm{C}$, respectively. As argued earlier, this is an expected result that can be attributed to the availability of greater thermal energy with higher substrate temperature, enabling the nucleation, coalescence, and growth of larger $\mathrm{SiC}$ grains and, therefore, leading to higher rms surface roughness with increased substrate temperature. 


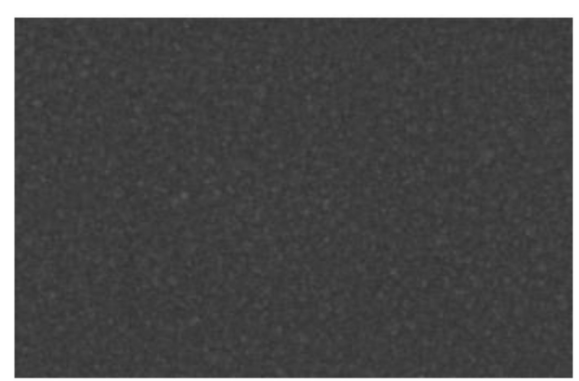

$\mathrm{TSCH} 650^{\circ} \mathrm{C}$

\begin{tabular}{|c|}
\hline RMS roughness \\
\hline $0.3 \mathrm{~nm}$ \\
\hline
\end{tabular}

(a)

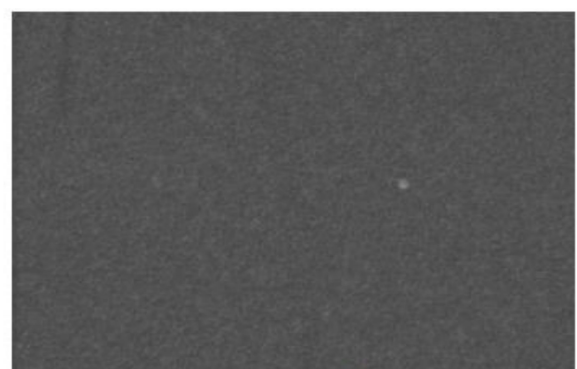

$\mathrm{TSCH} 700^{\circ} \mathrm{C}$

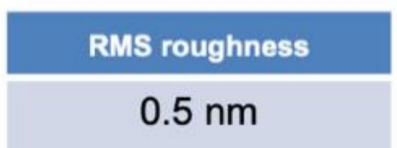

(b)

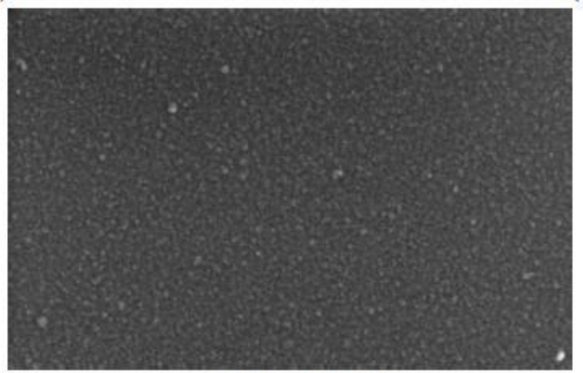

$\mathrm{TSCH} 800^{\circ} \mathrm{C}$

RMS roughness

$1.5 \mathrm{~nm}$

(c)

Figure 12. Scanning electron microscopy (SEM) micrographs for as-deposited SiC films grown from TSCH at: (a) $6500^{\circ} \mathrm{C}$, (b) $700{ }^{\circ} \mathrm{C}$, and (c) $800^{\circ} \mathrm{C}$.

\section{Conclusions}

We conducted a design of experiment (DOE) study to explore thermal chemical vapor deposition (TCVD) of SiC thin films grown from the single source precursor 1,3,5trisilacyclohexane (TSCH, onto c-Si (100) substrates. The as-deposited $\mathrm{SiC}$ films were analyzed by FTIR, XPS, spectroscopic ellipsometry, atomic force microscopy (AFM), and photoluminescence (PL) in the visible spectrum. Findings were compared to those for the TCVD of $\mathrm{SiC}$ films grown from the source precursor 1,1,3,3-tetramethyl-1,3-disilacyclobutane (TMDSB; $\mathrm{C}_{6} \mathrm{H}_{16} \mathrm{Si}_{2}$ ). TMDSB was selected here because it has been extensively tested by the current investigators for the growth of $\mathrm{SiC}$ films as a host matrix for photoluminescence studies in erbium-doped $\mathrm{SiC}$ ( $\mathrm{SiC}: \mathrm{Er}$ ). The current study led to the identification of an optimized process window for the formation of stoichiometric silicon carbide $(\mathrm{SiC})$ thin films from TSCH without the need for post-deposition annealing within a substrate temperature window of $650^{\circ}$ to $850^{\circ} \mathrm{C}$. Hydrogen content was below the detection limits of FTIR for as-deposited SiC films grown from TSCH at substrate temperatures above $750{ }^{\circ} \mathrm{C}$. To achieve similar results for $\mathrm{SiC}$ films grown using TMDSB, annealing at $1100^{\circ} \mathrm{C}$ was required.

In contrast to the $\mathrm{SiC}$ films grown from TMDSB, the as-deposited $\mathrm{SiC}$ samples grown using TSCH did not demonstrate any defect-induced PL and exhibited a drastic decrease in absorption in the visible range. Importantly, these findings suggest that the as-deposited SiC samples grown using TSCH are both hydrogen- and defect-free within the detection limits of the analytical techniques used, and could therefore serve as a more advantageous host matrix for myriad optical and optoelectronic applications. It is worth noting that the process does provide significant benefits in $\mathrm{BEOL}$ interconnect applications if the deposition can be further reduced from $650{ }^{\circ} \mathrm{C}$ to below $500{ }^{\circ} \mathrm{C}$. To this end, the authors plan to explore the addition of 
a non-hydrogenated direct or remote plasma to further activate the precursor decomposition reaction and drive the deposition temperature below $500{ }^{\circ} \mathrm{C}$, while maintaining film quality. Furthermore, the authors intend to study the growth of $\mathrm{SiC}$ on other substrates of interest for possible applications in high temperature $\mathrm{SiC}$ devices.

Author Contributions: Conceptualization: B.A. and A.E.K. Writing-original draft: A.E.K. and B.A. Writing, Review and editing: J.G., A.E.K. and B.A. Project Supervision: J.G. and A.E.K. All authors have read and agreed to the published version of this manuscript.

Funding: This research received no external funding.

Institutional Review Board Statement: Not applicable.

Informed Consent Statement: Not applicable.

Data Availability Statement: Not applicable.

Acknowledgments: The authors would like to acknowledge Alex E. Kaloyeros and Spyros Gallis for their invaluable contributions to the work presented here.

Conflicts of Interest: The authors declare no conflict of interest.

\section{References}

1. Kaloyeros, A.E.; Jové, F.A.; Goff, J.; Arkles, B. Review-Silicon nitride and silicon nitride-rich thin film technologies: Trends in deposition techniques and related applications. ECS J. Solid State Sci. Technol. 2017, 6, P691. [CrossRef]

2. Ivashchenko, V.I.; Kozak, A.O.; Porada, O.K.; Ivashchenko, L.A.; Sinelnichenko, O.K.; Lytvyn, O.S.; Tomila, T.V.; Malakhov, V.J. Characterization of SiCN thin films: Experimental and theoretical investigations. Thin Solid Films 2014, 569, 57-63. [CrossRef]

3. Marsi, N.; Majlis, B.Y.; Mohd-Yasin, F.; Abidin, H.E.Z.; Hamzah, A.A. A review: Properties of silicon carbide materials in mems application. Int. J. Nanoelectron. Mater. 2020, 13, 113-128.

4. Daviau, K.; Lee, K.K.M. High-pressure, high-temperature behavior of silicon carbide: A review. Crystals 2018, 8, 217. [CrossRef]

5. Lukin, D.M.; Guidry, M.A.; Vučković, J. Silicon Carbide: From Abrasives to Quantum Photonics. Opt. Photonics News 2021, 32, 34. [CrossRef]

6. Eddy, C.R.; Gaskill, D.K. Silicon carbide as a platform for power electronics. Science 2009, 324, 1398-1400. [CrossRef]

7. Roccaforte, F.; Fiorenza, P.; Vivona, M.; Greco, G.; Giannazzo, F. Selective doping in silicon carbide power devices. Materials 2021, 14, 3923. [CrossRef]

8. Gammon, P.M.; Chan, C.W.; Li, F.; Gity, F.; Trajkovic, T.; Pathirana, V.; Flandre, D.; Kilchytska, V. Development, characterisation and simulation of wafer bonded Si-on-SiC substrates. Mater. Sci. Semicond. Process 2018, 78, 69-74. [CrossRef]

9. Guidry, M.A.; Yang, K.Y.; Lukin, D.M.; Markosyan, A.; Yang, J.; Fejer, M.M.; Vučković, J. Optical parametric oscillation in silicon carbide nanophotonics. Optica 2020, 7, 1139. [CrossRef]

10. Son, N.T.; Anderson, C.P.; Bourassa, A.; Miao, K.C.; Babin, C.; Widmann, M.; Niethammer, M.; Ul Hassan, J.; Morioka, N.; Ivanov, I.G.; et al. Developing silicon carbide for quantum spintronics. Appl. Phys. Lett. 2020, 116, 190501. [CrossRef]

11. Tabassum, N.; Kotha, M.; Kaushik, V.; Ford, B.; Dey, S.; Crawford, E.; Nikas, V.; Gallis, S. On-Demand CMOS-Compatible Fabrication of Ultrathin Self-Aligned SiC Nanowire Arrays. Nanomaterials 2018, 8, 906. [CrossRef]

12. Tabassum, N.; Nikas, V.; Kaloyeros, A.E.; Kaushik, V.; Crawford, E.; Huang, M.; Gallis, S. Engineered telecom emission and controlled positioning of Er3+ enabled by SiC nanophotonic structures. Nanophotonics 2020, 9, 1425-1437. [CrossRef]

13. Rufangura, P.; Folland, T.G.; Agrawal, A.; Caldwell, J.D.; Iacopi, F. Towards low- loss on-chip nanophotonics with coupled graphene and silicon carbide: A review. J. Phys. Mater. 2020, 3, 32005. [CrossRef]

14. Chabi, S.; Kadel, K. Two-dimensional silicon carbide: Emerging direct band gap semiconductor. Nanomaterials 2020, $10,2226$. [CrossRef]

15. Gallis, S.; Efstathiadis, H.; Huang, M.; Nyein, E.E.; Hommerich, U.; Kaloyeros, A.E. Photoluminescence at 1540 nm from erbium-doped amorphous silicon carbide films. J. Mater. Res. 2004, 19, 2389-2393. [CrossRef]

16. Boccard, M.; Holman, Z.C. Amorphous silicon carbide passivating layers for crystalline-silicon-based heterojunction solar cells. J. Appl. Phys. 2015, 118, 65704. [CrossRef]

17. Kleinová, A.; Huran, J.; Sasinková, V.; Perný, M.; Šály, V.; Packa, J. FTIR Spectroscopy of Silicon Carbide Thin Films Prepared by PECVD Technology for Solar Cell Application. In Proceedings of the Reliability of Photovoltaic Cells, Modules, Components, and Systems VIII, San Diego, CA, USA, 9-13 August 2015; Dhere, N.G., Wohlgemuth, J.H., Jones-Albertus, R., Eds.; SPIE: Bellingham, WA, USA, 2015; Volume 9563, pp. 166-173.

18. Graef, E.; Huizing, B.; Mahnkopf, R.; Hidemi Ishiuchi, J.; Hayashi, Y.; Ikumi, N.; Miyakawa, H.; Choi, K.; Hoon Choi, J.; Pam, T.; et al. International Technology Roadmap for Semiconductors 2.0; IEEE: San Jose, CA, USA, 2015.

19. King, S.W. Dielectric barrier, etch stop, and metal capping materials for state of the art and beyond metal interconnects. ECS J. Solid State Sci. Technol. 2015, 4, N3029-N3047. [CrossRef] 
20. Wrobel, A.M.; Walkiewicz-Pietrzykowska, A.; Uznanski, P. Thin a-SiC: H Films Formed by Remote Hydrogen Microwave Plasma CVD using Dimethylsilane and Trimethylsilane Precursors. Chem. Vap. Depos. 2014, 20, 112-117. [CrossRef]

21. Yu, E.; Cho, S.; Park, B.G. A silicon-compatible synaptic transistor capable of multiple synaptic weights toward energy-efficient neuromorphic systems. Electronics 2019, 8, 1102. [CrossRef]

22. Liu, L.; Zhao, J.; Cao, G.; Zheng, S.; Yan, X. A Memristor-Based Silicon Carbide for Artificial Nociceptor and Neuromorphic Computing. Adv. Mater. Technol. 2021, 6, 1-9. [CrossRef]

23. Pessoa, R.S.; Medeiros, H.S.; Fraga, M.A.; Galvao, N.K.M.; Sagas, J.C.; Maciel, H.S.; Massi, M.; da Silva Sobrinho, A.S. Lowpressure deposition techniques of silicon carbide thin films: An overview. Mater. Sci. Res. J. 2013, 7, $329-345$.

24. Weidman, T.; Schroeder, T. Method for the Deposition of Silicon Carbide ans Silicon Carbonitride Films. U.S. Patent 8.440,571 B2, 14 May 2013.

25. Underwood, B.; Mallick, A.; Ingle, N.K. Molecular Layer Deposition of Silicon Carbide. U.S. Patent 8,753,985 B1, 17 June 2014.

26. Mallick, A.; Ingle, N.K. Flowable Silicon-and-Carbon Layers. U.S. Patent 2013/0217239 A1, 22 August 2013.

27. Nardin, T.; Gouze, B.; Cambedouzou, J.; Meyer, D.; Diat, O. Processing and Properties of Advanced Ceramics and Composites VII: Ceramic Transactions; Mahmoud, M.M., Bhalla, A., Bansal, N.P., Singh, J.P., Castro, R.H.R., Manjooran, N.J., Pickrell, G., Johnson, S., Brennecka, G., Singh, G., et al., Eds.; The American Ceramic Society: Columbus, OH, USA, 2015; Volume 252, pp. $221-227$.

28. Gallis, S.; Nikas, V.; Eisenbraun, E.; Huang, M.; Kaloyeros, A. On the Effects of Thermal Treatment on the Composition, Structure, Morphology, and Optical Properties of Hydrogenated Amorphous Silicon-Oxycarbide. J. Mater. Res. 2009, 24, $2561-2573$. [CrossRef]

29. Gallis, S.; Nikas, V.; Huang, M.; Eisenbraun, E.; Kaloyeros, A.E. Comparative study of the effects of thermal treatment on the optical properties of hydrogenated amorphous silicon-oxycarbide. J. Appl. Phys. 2007, 102, 024302. [CrossRef]

30. Nevin, W.A.; Yamagishi, H.; Yamaguchi, M.; Tawada, Y. Emission of blue light from hydrogenated amorphous silicon carbide. Nature 1994, 368, 529-531. [CrossRef] 